\title{
PENGARUH TANGGUNG JAWAB SOSIAL DAN MODAL INTELEKTUAL TERHADAP KINERJA KEUANGAN PERUSAHAAN (Studi pada BUMN yang Terdaftar di Bursa Efek Indonesia)
}

\author{
Rahmatiah $^{1}$, Muliati $^{2}$, Mustamin ${ }^{2}$ dan Noor Riefma Hidayah ${ }^{3}$ \\ ${ }^{1}$ Mahasiswa Jurusan Akuntansi Fakultas Ekonomi Universitas Tadulako, Palu \\ 2Dosen Universitas Tadulako, Palu \\ ${ }^{3}$ Dosen IAIN Palu
}

\begin{abstract}
This research aims to know and analyze the effect of social responsibility and intellectual capital both simultaneously and partially to company's financial performance at state-owned enterprise (BUMN) listed on the Indonesia Stock Exchange. The type of research is quantitative and with the using secondary data. The total sample is nine companies which the research period is 2011-2015. Results show that simultaneously corporate social responsibility and intellectual capital influence the finance performance. Corporate social responsibility do not have effect while intellectual capital influence the financial performance partially.
\end{abstract}

Keywords: Corporate Social Responsibility, Intellectual Capital, Financial Performance

\begin{abstract}
ABSTRAK
Penelitian ini bertujuan untuk menganalisis pengaruh tanggung jawab sosial dan modal intelektual baik secara simultan maupun secara parsial terhadap kinerja keuangan perusahaan pada perusahaan Badan Usaha Milik Negara (BUMN) yang terdaftar di Bursa Efek Indonesia. Jenis penelitian ini adalah penelitian kuantitatif dengan menggunakan data sekunder. Total perusahaan yang menjadi sampel penelitian adalah sembilan perusahaan yang mana periode penelitian meliputi 2011-2015. Hasil penelitian menunjukkan bahwa secara simultan tanggung jawab sosial dan modal intelektual berpengaruh signifikan terhadap kinerja keuangan. Tanggung jawab sosial secara parsial tidak berpengaruh sedangkan modal intelektual berpengaruh secara parsial terhada kinerja keuangan.
\end{abstract}

Kata kunci: Tanggung Jawab Sosial, Modal Intelektual, Kinerja Keuangan

Jurnal Akun Nabelo: Jurnal Akuntansi Netral, Akuntabel, Objektif

Volume 1/Nomor 1/Juli 2018 Jurusan Akuntansi FE-Universitas Tadulako

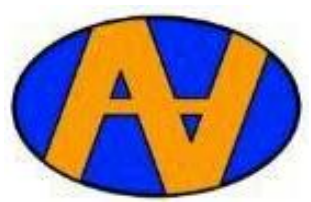




\section{A. Pendahuluan}

Persaingan bisnis yang ketat merupakan salah satu pemicu pertumbuhan ekonomi yang cukup pesat. Banyak perusahaan melakukan modernisasi dan mengupayakan berbagai kemajuan di bidang ekonomi. Perusahaanperusahaan mulai mengubah bisnis yang berdasarkan tenaga kerja (labour based business) ke arah bisnis berdasarkan pengetahuan (knowledge based business), dengan karakteristik utamanya adalah ilmu pengetahuan, agar tetap bertahan. Perubahan ekonomi yang memiliki karakteristik berbasis ilmu pengetahuan membuat kemakmuran suatu perusahaan akan bergantung pada penciptaan transformasi dan kapitalisasi pengetahuan itu sendiri. Sistem manajemen yang berbasis pengetahuan memiliki modal yang berbasis pada pengetahuan dan teknologi. Ilmu pengetahuan dan teknologi yang tepat dapat menghasilkan sumber daya yang efisien dan ekonomis sehingga memberikan keunggulan bagi perusahaan.

Kemakmuran sebuah perusahaan dapat dilihat dari kinerjanya. Perusahaan yang memiliki kinerja yang baik dapat dikatakan makmur atau berhasil. Setiap perusahaan tentunya menginginkan kinerja yang baik tak terkecuali Badan Usaha Milik Negara (BUMN). Praditya (2016) mengemukakan Kementerian Badan Usaha Milik Negara (BUMN) mencatat masih ada puluhan BUMN yang kinerjanya tidak memuaskan pada tahun 2015 dan terdapat 18 BUMN yang mengalami kerugian. $\mathrm{Hal}$ ini sangat disayangkan mengingat BUMN memiliki peran penting dalam mendukung pembangunan ekonomi di Indonesia.

Keberhasilan yang dicapai oleh perusahaan harus diikuti dengan kepedulian perusahaan terhadap masyarakat serta lingkungan. Namun masih terdapat beberapa perusahaan yang hanya memikirkan keuntungan semata. Hal ini juga terjadi di Indonesia, di mana banyak perusahaan yang hanya beorientasi pada maksimalisasi laba untuk menunjukkan kinerjanya seperti yang terjadi dalam kasus Lumpur Lapindo. Beberapa pendapat menyatakan bahwa lumpur Lapindo disebabkan oleh gempa dan faktor hidrotermal. Utomo (2015) mengemukakan dalam makalah yang ditulis oleh tim ilmuwan Australia dan Amerika Serikat di jurnal Nature Geosciences menyimpulkan bahwa erupsi lumpur tidak dipicu oleh alam tetapi konsekuensi pengeboran. Permasalahan seperti ini seharusnya tidak terjadi apabila perusahaan beraktivitas dengan disertai suatu kepedulian terhadap masyarakat dan lingkungan.

\section{B. TINJAUAN PUSTAKA}

Menyadari bahwa pentingnya suatu perusahaan memperhatikan sisi lingkungan dan sosial, pada tahun 2007 Pemerintah Indonesia menerbitkan regulasi yang mengatur tentang Tanggung Jawab Sosial Perusahaan atau Corporate Social Responsibility (CSR) yaitu Undang-Undang No. 40 Tahun 2007 tentang Perseroan Terbatas yang mana dalam pasal 74 menyebutkan bahwa "Perseroan yang menjalankan kegiatan usahanya di bidang dan/atau berkaitan dengan sumber daya alam wajib melaksanakan tanggung jawab sosial dan lingkungan". Pada tahun 2012, Peraturan Pemerintah No. 47 Tahun 2012 diterbitkan mengenai Tanggung Jawab Sosial dan Lingkungan Perseroan Terbatas.

Jelita (2012) menyatakan bahwa modal intelektual dan tanggung jawab sosial atau corporate social responsibility secara bersama-sama (simultan) berpengaruh positif dan signifikan terhadap kinerja keuangan perusahaan. Pengaruh positif dari modal intelektual dan tanggung jawab sosial terhadap kinerja keuangan perusahaan memiliki arti bahwa semakin tinggi modal intelektual dan tanggung 
Rahmatiah, Muliati, Mustamin \& Noor

jawab sosial atau corporate social responsibility yang dihasilkan oleh perusahaan maka kinerja keuangan perusahaan akan semakin tinggi pula. Berdasarkan uraian di atas, maka hipotesis yang pertama dalam penelitian ini adalah:

H1: Tanggung jawab sosial dan modal intelektual secara simultan berpengaruh positif dan signifikan terhadap kinerja keuangan perusahaan. Tanggung jawab sosial perusahaan biasa dikenal dengan Corporate Social Responsibility yang disingkat menjadi CSR. Definisi tanggung jawab sosial menurut World Business Council on Sustainable Development adalah komitmen dari bisnis/perusahaan untuk berperilaku etis dan berkontribusi terhadap pembangunan ekonomi yang berkelanjutan, seraya meningkatkan kualitas hidup karyawan dan keluarganya, komunitas lokal dan masyarakat luas. Wacana tanggung jawab sosial perusahaan (corporate social responsibility) yang kini menjadi isu sentral yang semakin populer dan bahkan ditempatkan pada posisi yang penting, karena itu kian banyak pula kalangan dunia usaha dan pihak-pihak terkait mulai merespon wacana ini, tidak sekedar mengikuti tren tanpa memahami esensi dan manfaatnya.

Pustikaningsih (2011) meneliti tentang pengaruh corporate social responsibility (CSR) terhadap kinerja keuangan perusahaan jasa. Sampel penelitiannya meliputi 148 perusahaan jasa yang ada di Yogyakarta. Penelitian tersebut menggunakan Structural Equation Modeling (SEM) dengan software AMOs versi 16. Hasil dari penelitian tersebut menunjukkan bahwa corporate social responsibility berpengaruh terhadap kinerja keuangan perusahaan. Berdasarkan uraian tersebut maka hipotesis yang kedua pada penelitian ini adalah:

H2: Tanggung jawab sosial secara parsial berpengaruh positif dan signifikan terhadap kinerja keuangan perusahaan.
Ulum (2009) menyatakan

intellectual capital umumnya

diidentifikasi sebagai perbedaan antara nilai pasar perusahaan (bisnis perusahaan) dan nilai buku dari aset perusahaan tersebut atau dari financial capital-nya. Sawarjuwono dan Kadir (2003) mengemukakan intellectual capital dapat didefinisikan sebagai jumlah dari apa yang dihasilkan oleh tiga elemen utama organisasi (human capital, structural capital, costumer capital) yang berkaitan dengan pengetahuan dan teknologi yang dapat memberikan nilai lebih bagi perusahaan berupa keunggulan bersaing organisasi.

Pulic (1998) menyatakan bahwa pengukuran efisiensi modal intelektual VAIC ${ }^{\mathrm{TM}}$ dapat membantu manajer untuk meningkatkan potensi perusahaannya berdasarkan kinerja bisnis saat ini. Selain itu, hasil penelitian terdahulu juga menyatakan bahwa efisiensi modal intelektual memiliki nilai prediksi terhadap kinerja keuangan perusahaan (Chen et al., 2005; Tan et al., 2007; Ulum, 2009). Berdasarkan uraian sebelumnya maka hipotesis yang ketiga penelitian ini adalah:

H3: Modal intelektual secara parsial berpengaruh positif dan signifikan terhadap kinerja keuangan perusahaan. 


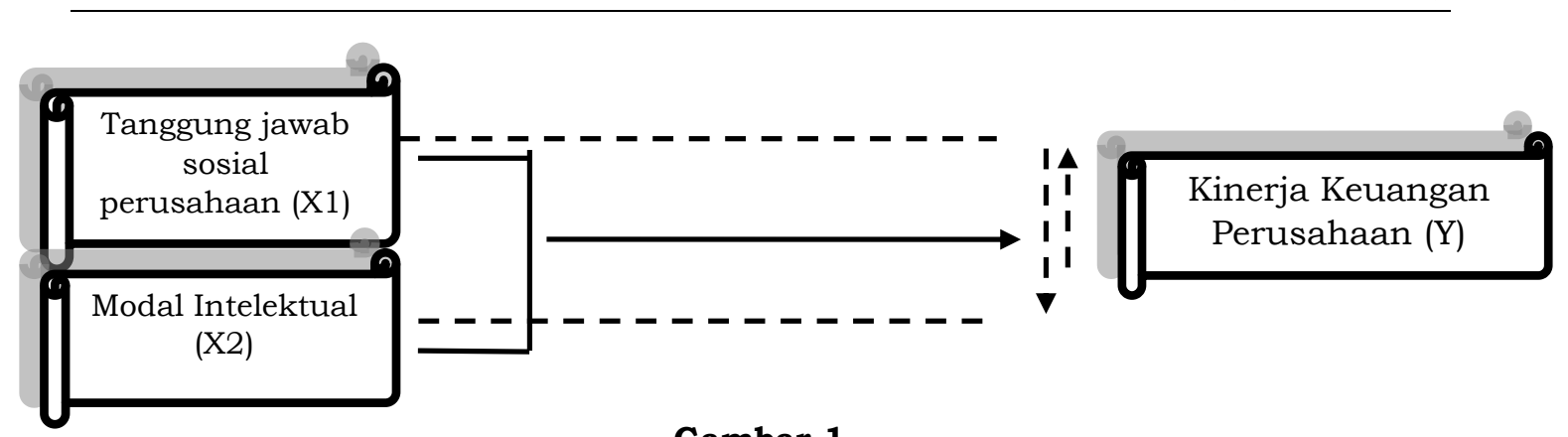

\section{Gambar 1}

Kerangka Pemikiran Penelitian

Sumber: Diolah peneliti, 2017

Keterangan:

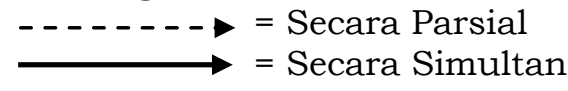

\section{METODE PENELITIAN}

Subjek penelitian ini adalah Badan Usaha Milik Negara (BUMN) yang terdaftar dalam Bursa Efek Indonesia (BEI) dari tahun 20112015. Jenis penelitian ini adalah penelitian kuantitatif dengan menggunakan sumber data sekunder. Dalam penelitian ini peneliti menggunakan laporan keuangan BUMN yang terdaftar di Bursa Efek Indonesia pada tahun 2011-2015. Populasi dalam penelitian ini adalah perusahaan BUMN yang terdaftar di Bursa Efek Indonesia yang berjumlah 20 perusahaan. Metode pengambilan sampel dilakukan dengan menggunakan metode purposive sampling yaitu teknik penentuan sampel dengan pertimbangan tertentu.

Metode analisis penelitian ini menganalisis data dengan cara mendeskripsikan atau menggambarkan data yang telah terkumpul mengenai tanggung jawab sosial, modal intelektual dan kinerja keuangan. Analisis dilakukan melalui tahapan uji asumsi klasik yang meliputi uji normalitas, heterokedastisitas, autokorelasi dan multikolinearitas serta pengujian hipotesis dengan uji $\mathrm{F}$ dan $\mathrm{t}$.

\section{HASIL DAN PEMBAHASAN}

Tabel 1

Hasil Uji Regresi Linear Berganda Coefficients $^{a}$

\begin{tabular}{|c|c|c|c|c|}
\hline \multirow[b]{2}{*}{ Model } & & \multicolumn{2}{|c|}{$\begin{array}{c}\text { Unstandardized } \\
\text { Coefficients }\end{array}$} & \multirow{2}{*}{$\begin{array}{c}\text { Standardized } \\
\text { Coefficients }\end{array}$} \\
\hline & & B & Std. Error & \\
\hline 1 & (Constant) & .044 & .034 & \\
\hline & CSR & -.111 & .088 & -.087 \\
\hline & VAICTM & .030 & .002 & .884 \\
\hline & $\begin{array}{l}\text { Simultan : } \\
\text { Signifikan : }\end{array}$ & & & \\
\hline
\end{tabular}

Sumber: Output SPSS, 2017

Berdasarkan hasil pengujian regresi diperoleh bentuk persamaan regresi sebagai berikut:

$Y=0,044-0,111$ CSR $+0,030$ VAIC $^{T M}+e$

\section{D.1 Uji Simultan (Uji F)}

Berdasarkan pengolahan atas data penelitian menggunakan perhitungan SPSS diperoleh nilai 
F hitung sebesar 85,577 dengan tingkat signifikan 0,000. Dengan mengambil tarif signifikan $a=5 \%$ $(0,05)$ maka $F_{\text {tabel }}$ sebesar 3,20 sehingga $F_{\text {hitung }} \geq F_{\text {tabel }}(85,577 \geq$ $3,20)$ dengan tingkat signifikan lebih kecil dari tarif signifikan $(0,000<0,05)$. Oleh karena itu, kaidah keputusan yang diambil adalah HO ditolak $\mathrm{Ha}$ diterima. Dengan demikian dapat ditarik kesimpulan bahwa tanggung jawab sosial dan modal intelektual secara simultan berpengaruh positif dan secara statistik pengaruh tersebut signifikan terhadap kinerja keuangan perusahaan BUMN yang terdaftar di Bursa Efek Indonesia.

Hasil penelitian ini sejalan dengan penelitian yang dilakukan oleh Jelita (2012) yang mana mengemukakan bahwa tanggung jawab sosial dan modal intelektual secara simultan berpengaruh positif dan signifikan terhadap kinerja keuangan perusahaan. Pengaruh positif dari modal intelektual dan tanggung jawab sosial memiliki arti bahwa semakin tinggi tanggung jawab sosial dan modal intelektual yang dihasilkan oleh perusahaan maka kinerja keuangan perusahaan akan semakin tinggi pula.

\section{D.2 Uji Parsial (Uji t)}

Berdasarkan hasil uji statistik t menunjukan bahwa tanggung jawab sosial perusahaan atau Corporate Social Responsibility (CSR) secara parsial tidak berpengaruh signifikan terhadap kinerja keuangan perusahaaan/ return on asset (ROA), sehingga hipotesis kedua (H2) ditolak. Diketahui nilai signifikan tanggung jawab sosial sebesar 0,214 dimana $0,214>5 \%(0,05)$ artinya bahwa hubungan tanggung jawab sosial terhadap kinerja keuangan perusahaan BUMN yang terdaftar di Bursa Efek Indonesia tidak signifikan.

Dari hasil koefisien regresi tanggung jawab sosial (X1) sebesar 0,111 . Dalam hal ini berarti setiap penambahan 0,01 atau $1 \%$ dari tanggung jawab sosial di mana nilai koefisien modal intelektual (X2) tetap, maka kinerja keuangan perusahaan BUMN yang terdaftar di
Bursa Efek Indonesia (Y) akan berkurang sebesar 0,111 atau $11,1 \%$. Namun sebaliknya, jika tanggung jawab sosial berkurang 0,01 atau $1 \%$ di mana nilai dapat dibuktikan dengan melihat hasil statistik yang menunjukkan nilai koefisien variabel modal intelektual (X2) tetap, maka kinerja keuangan perusahaan BUMN yang terdaftar di Bursa Efek Indonesia akan bertambah sebanding dengan penambahan tanggung jawab sosial yaitu sebesar 0,111 atau $11,1 \%$.

Untuk tingkat keyakinan 95\% $(a=5 \%)$ sehingga diperoleh nilai $t_{\text {tabel }}$ sebesar 1,689 dan berdasarkan perhitungan SPSS diperoleh nilai $t_{\text {hitung }}$ sebesar $-1,261$. Sehingga nilai $-t_{\text {hitung }}>-t_{\text {tabel }}(-1,261>-1,689)$. Dari hasil tersebut di mana nilai $t_{\text {hitung }}$ lebih kecil dari nilai $t_{\text {tabel }}$ dan tingkat signifikan tanggung jawab sosial lebih kecil dari 0,05 (5\%). Maka kaidah keputusannya adalah HO diterima dan Ha ditolak.

Pengaruh negatif dari tanggung jawab sosial memiliki arti bahwa semakin tinggi tanggung jawab sosial yang dihasilkan oleh perusahaan maka kinerja keuangan perusahaan akan semakin rendah. Hasil penelitian ini sejalan dengan yang dilakukan oleh Jelita (2012) dan Yaparto (2013) yang menunjukkan bahwa tanggung jawab sosial secara parsial tidak bepengaruh secara signifikan dan berpengaruh negatif terhadap kinerja keuangan perusahaan. Secara teoritis maupun secara praktis hasilnya berbanding terbalik, jika tanggung jawab sosial meningkat maka kinerja keuangan menurun. Hal ini dikarenakan pelaksanaan tanggung jawab sosial membutuhkan biaya yang pada akhirnya akan menjadi beban yang mengurangi pendapatan sehingga dapat mengurangi laba perusahaan.

Berdasarkan hasil uji statistik t menunjukkan bahwa modal intelektual atau intellectual capital berpengaruh terhadap kinerja keuangan perusahaan (return on asset/ROA). Hal ini dapat dibuktikan dengan melihat hasil statistik yang menunjukkan nilai $t_{\text {hitung }}$ sebesar 12,847 lebih besar 
dari t tabel sebesar 1,689 yang diperoleh dan nilai signifikan sebesar 0,000 lebih kecil dari nilai signifikan yang telah ditentukan yaitu 0,05 atau $5 \%$. Hal ini berarti bahwa modal intelektual atau intellectual capital berpengaruh signifikan terhadap kinerja keuangan perusahaan (return on asset/ROA).

Berdasarkan teori Bontis et al. (1998) dalam Ulum (2009) yang menyatakan bahwa modal intelektual (intellectual capital) mencerminkan sumber daya yang dimiliki perusahaan berupa pengetahuan untuk menghasilkan aset yang lebih tinggi. Modal kerja intelektual mencakup semua pengetahuan karyawan, organisasi dan kemampuan mereka untuk menciptakan nilai tambah dan menyebabkan keunggulan kompetitif berkelanjutan. Jika perusahaan berhasil dalam mengelola modal intelektual (intellectual capital), maka hal itu dapat meningkatkan kinerja keuangan perusahaan.

Hasil penelitian ini mengindikasikan bahwa modal intelektual (intellectual capital) yang dimiliki perusahaan telah digunakan dan dikembangkan secara maksimal. Hal ini dapat dilihat dari hasil komponen VAIC (Value Added Intellectual Coefficient) yaitu komponen VAHU (Value added Human Capital) memiliki nilai ratarata tertinggi yaitu sebesar 116,77. Hal ini menunjukkan bahwa hubungan antara VA dan HC (kemampuan untuk menciptakan nilai HC/human capital dalam sebuah perusahaan) lebih maksimal digunakan dan dikembangkan dalam perusahaan dibandingkan dengan VACA (Value Added Capital Employed) dan STVA (Structural Capital Value Added).

Hasil komponen VACA (Value Added Capital Employed) memiliki nilai rata-rata sebesar 14,02 . Hal ini menunjukan indikator bahwa VA diciptakan oleh satu unit modal fisik. Sedangkan STVA (Structural Capital Value Added) memiliki nilai rata-rata sebesar 22,56. Hal ini menunjukan kontribusi modal struktural berhasil memanfaatkan dan memaksimalkan human capital (kombinasi organisasi dengan kemampuan orang yang ada dalam perusahaan untuk memecahkan atau memberikan solusi pada masalah bisnis), structural capital (kemampuan organisasi dalam memenuhi proses rutinitas perusahaan dan strukturnya yang mendukung usaha karyawan untuk menghasilkan kinerja intelektual yang optimal serta kinerja bisnis secara keseluruhan), customer capital (hubungan yang harmonis yang dimiliki oleh perusahaan dengan para mitranya seperti pemerintah, pasar, pemasok dan pelanggan, bagaimana loyalitass pelanggan terhadap perusahaan sehingga perusahaan dapat menciptakan nilai tambah dan menyebabkan keunggulan kompetitif berkelanjutan bagi perusahaan).

Hasil penelitian ini sejalan dengan penelitian yang dilakukan oleh Ritonga dan Andriyanie (2011) yang menyatakan bahwa modal intelektual (intellectual capital) secara parsial berpengaruh positif dan signifikan terhadap kinerja keuangan perusahaan/return on asset (ROA). Pengaruh positif dari modal intelektual terhadap kinerja keuangan perusahaan memiliki arti bahwa semakin tinggi modal intelektual yang dihasilkan oleh perusahaan maka kinerja keuangan perusahaan akan semakin tinggi pula. Hasil penelitian ini tidak sejalan dengan penelitian yang dilakukan oleh Ciptaningsih (2013) yang menunjukan bahwa pengungkapan modal intelektual tidak berpengaruh terhadap kinerja keuangan perusahaan.

\section{E. PENUTUP}

Berdasarkan hasil penelitian ini dapat disimpulkan bahwa tanggung jawab sosial yang diukur dengan CSRI tidak berdampak pada meningkatnya kinerja keuangan perusahaan BUMN yang ada di Indonesia. Sementara itu, penelitian ini juga berhasil mengungkap bahwa modal intelektual 
perusahaan merupakan salah satu faktor determinan kinerja keuangan perusahaan yang penting.

Interpretasi hasil penelitian ini terbatas pada perusahaan BUMN yang terdaftar di Bursa Efek Indonesia. Maka dari itu, penelitian selanjutnya diharapkan memperluas sampel penelitian dengan mengambil seluruh perusahaan yang terdaftar di Bursa Efek Indonesia sebagai sampel. Hal ini bertujuan agar kesimpulan yang dihasilkan dari penelitian memiliki cakupan yang lebih luas. Peneliti selanjutnya juga diharapkan dapat menambah variabel independen lain ke dalam model penelitian ini.

Perusahaan diharapkan lebih menyadari pentingnya isu tanggung jawab sosial perusahaan di masa depan sehingga perusahaan mau melaksanakan aktivitas tanggung jawab sosial secara nyata dengan memaskimalkan dampak positif dan meminimalkan dampak negatif dari kegiatan operasi perusahaan. Apabila perusahaan mempertimbangkan kegiatan tanggung jawab sosial perusahaan dalam jangka panjang, perusahaan dapat menikmati kinerja pasar yang baik dan juga akan dinikmati oleh masyarakat secara umum. Pengukuran indeks tanggung jawab sosial perusahaan harus terus mengikuti perkembangan yang ada dari berbagai badan internasional yang terkait dengan tanggung jawab sosial perusahaan dan disesuaikan dengan keadaan di Indonesia.

\section{DAFTAR PUSTAKA}

Agustine, Ira, 2014, Pengaruh Corporate Social Responsibility terhadap Nilai Perusahaan. Jurnal Finesta, 2.

Anggraini, Fr. Reni Retno, 2006, Pengungkapan Informasi Sosial dan Faktor-Faktor yang Mempengaruhi Pengungkapan Informasi Sosial dalam Laporan Tahunan (Studi Empiris pada PerusahaanPerusahaan yang Terdaftar di BEJ). Makalah ini disajikan pada Simposium Nasional
Akuntansi 9, Padang, 23-26 Agustus.

Belal, A., 2001, A Study of Corporate Social Disclosures in Bangladesh. Managerial Auditing Journal, 16, p 274289.

Bungin, Burhan, 2013, Metodologi Penelitian Kuantitatif, Surabaya, Penerbit Kencana Prenada Media Group.

Chariri, Anis, 2008, Kritik Sosial Atas Pemakaian Teori Dalam Penelitan Pengungkapan Sosial dan Lingkungan. Jurnal Maksi, 8, p 151-169.

Ciptaningsih, Tri, 2013, Uji Pengaruh Modal Intelektual terhadap Kinerja Keuangan BUMN yang Go Public di Indonesia. Jurnal Manajemen Teknologi, 12.

Ghozali, Imam, 2012, Aplikasi Analisis Multivariate dengan Program SPSS, Semarang, Badan Penerbit Undip.

Hadi, Syamsul, 2009, Metodologi Penelitian Kuantitatif untuk Akuntansi dan Keuangan, Yogyakarta, Penerbit Ekonisia.

Harahap, Sofyan Syafri, 1998, Analisis Kritis Atas Laporan Keuangan, Jakarta, Persada.

Ikatan Akuntansi Indonesia, 2010, Pernyataan Standar Akuntansi Keuangan Nomor 19 (Revisi 2010) tentang Aset Tak Berwujud, Jakarta, IAI.

Ikatan Akuntansi Indonesia, 2007, Standar Akuntansi Keuangan, Edisi 2007, Jakarta, Salemba Empat.

Jumingan, 2011, Analisis Laporan Keuangan. Jakarta, Penerbit PT Bumi Aksara.

Jelita, Dilla, 2012, Pengaruh Modal Intelektual dan Corporate Social Responsibility terhadap Kinerja Keuangan (Survey pada Perusahaan Manufaktur yang Terdaftar di Bursa Efek 
Indonesia pada Tahun 2012) E-journal S1 Akuntansi Universitas Siliwangi, 3.

Kasmir, 2014, Analisis Laporan Keuangan, Jakarta, Penerbit PT Raja Grafindo Persada.

Pulic, A., 1998, Measuring the Performance of Intellectual Potential in Knowledge Economy. Makalah disajikan padathe 2nd McMaster Word Congress on Measuring and Managing Intellectual Capital by the Austrian Team for Intellectual Potential, available at www.vaic-on.net.

Purnomosidhi, Bambang, 2006, Praktik Pengungkapan Modal Intelektual pada Perusahaan Publik di BEJ. Jurnal Riset Akuntansi Indonesia, 9, p 120.

Riyanto, Bambang, 2001, DasarDasar Pembelajaan Perusahaan, Yogyakarta, BPFT Yogyakarta.

Sartono, Agus, 2001, Manajemen Keuangan Teori dan Aplikasi, Yogyakarta, BPFT.

Sawarjuwono, T. dan A. P. Kadir, 2003, Intellectual Capital: Perlakuan, Pengukuran, dan Pelaporan (Sebuah Library Research). Jurnal Akuntansi dan Keuangan, 5, p 35-57.

Sucipto, 2003, Penilaian Kinerja Keuangan, Medan, Universitas Sumatera Utara.

Sutopoyudo, 2009, Pengaruh Penerapan Corporate Social Responsibility (CSR) terhadap Profitabilitas Perusahaan.
Sutopoyudo's Weblog at http://www.wordpress.com.

(Diakses tanggal 15 Desember 2014).

Sugiyono, 2011, Statistik untuk Penelitian, Bandung, Penerbit Alfabeta.

Sugiyono, 2013, Metode Penelitian Bisnis (Pendekatan Kuantitatif, Kualitatif, dan R\&D), Bandung, Penerbit Alfabeta.

Titisari, Kartika Hendra dan Eko Suwardi, 2010, Corporate Social Responsibility (CSR) dan Kinerja Perusahaan. Makalah disajikan pada Simposium Nasional Akuntansi XII.

Ulum, Ihyaul, 2007, Pengaruh Intellectual Capital terhadap Kinerja Keuangan Perusahaan Perbankan di Indonesia, Semarang, Universitas Diponegoro.

Ulum, Ihyaul, 2009, Intellectual Capital: Konsep dan Kajian Empiris, Yogyakarta, Graha Ilmu.

Utomo, Yunanto Wiji, 2015, Studi Baru Teori Menggugat Teori Penyebab Bencana Lumpur Lapindo. Diakses melalui: <http://sains.kompas.com/re ad/2015/07/08/17085161/St udi.Baru.Menggugat.Teori.Pen yebab.Bencana.Lumpur.Lapin do $>[22 / 08 / 2016]$ [13.15].

www.idx.co.id (Diakses pada 28 November 2014). 